\title{
Influence of Truck Transportation of Calves on Their Cellular Immune Function
}

\author{
Hideo MURATA, Hideyuki TAKAHASHI, and Hideto MATSUMOTO \\ Fourth Research Division, National Institute of Animal Health, 3-1-1 Kannondai, Yatabe-machi, Tsukuba-gun, \\ Ibaraki 305, Japan
}

(Recrived 7 March 1985/Accepted 8 June 1985)

\begin{abstract}
Effects of 1 hour transportation by a truck on cellular immune function were investigated in Holstein castrated calves of 6 months of age. Mitogen-induced blastogenesis of lymphocytes and Nitroblue tetrazolium (NBT) reduction activity of phagocytes in peripheral blood were determined before and 6 and 24 hours after the transportation and compared with those of control animals. Increases were observed in both of the activities 6 hours after the transportation. The increments returned to the initial level within 24 hours. These results suggest a temporary enhancement of cellular immune function due to the transportation.-KEY WORDS: calf, cellular immunity, truck transportation.
\end{abstract}

Jpn. J. Vet. Sci. 47(5): 823-827, 1985

Transportation of calves by truck often leads to the increased incidence of diseases and mortality [3, 13]. It has been suggested that the transportation may alter the susceptibility of calves to diseases by disturbing their immune system [5].

From this point of view, many workers have investigated the influence of transportation on blood constituents related to humoral immune function $[4,6,12]$. The influence on the cellular immune events, however, has recently begun to be investigated $[1,6]$.

The present study was carried out to ascertain the influence of transportation on the cellular immune function of calves by evaluating mitogen-induced blastogenesis of lymphocytes and Notroblue tetrazolium (NBT) reduction activity of phagocytes in peripheral blood. Plasma cortisol level was also evaluated.

Ten Holstein castrated calves, 6 months of age, were divided into two groups, i.e., transported and control. The former $(n=6)$ was transported for 1 hour by a truck with hood on a flat road with an average velocity of $40 \mathrm{~km} /$ hour. The animals were then kept separately in single pens. Heparinized blood was collected before (10:00 a.m.), 6 hours (5:00 p.m.) and 24 hours (ca. 10:00 a.m. of next day) after the transportation. The control group $(n=4)$ was kept in the pens during the experiment and was bled by the same manner with the transported group. During the experiment, feed (hay cubes and concentrates) was given 7 hours after the transportation (6:00 p.m.) whereas water was freely accessible except for the period of the transportation $(10: 00$ to 11:00 a.m.) in both groups.

Lymphocytes, isolated by density gradient centrifugation $\left(50 \mu l\right.$ at $4 \times 10^{6}$ cells $/ \mathrm{ml}$ in RPMI 1640 containing 20\% heat-inactivated fetal calf serum), were added in triplicate to wells of a 96-well microtiter plate. They were mixed with $50 \mu l$ of mitogen-free RPMI 1640 or $50 \mu \mathrm{l}$ of three different mitogens, i.e., phytohemmaglutinin-P (PHA-P, Difco, USA, $\times 640 / \mathrm{m} l$ ), concanavalin A (Con A, Boehringer-Manheim, West Germany, 20 $\mu \mathrm{g} / \mathrm{m} l$ ) or pokeweed mitogen (PWM, P-L Biochemicals Inc., USA, $20 \mu \mathrm{g} / \mathrm{m} l$ ), in RPMI 1640 and were incubated at $37^{\circ} \mathrm{C}$ in a 

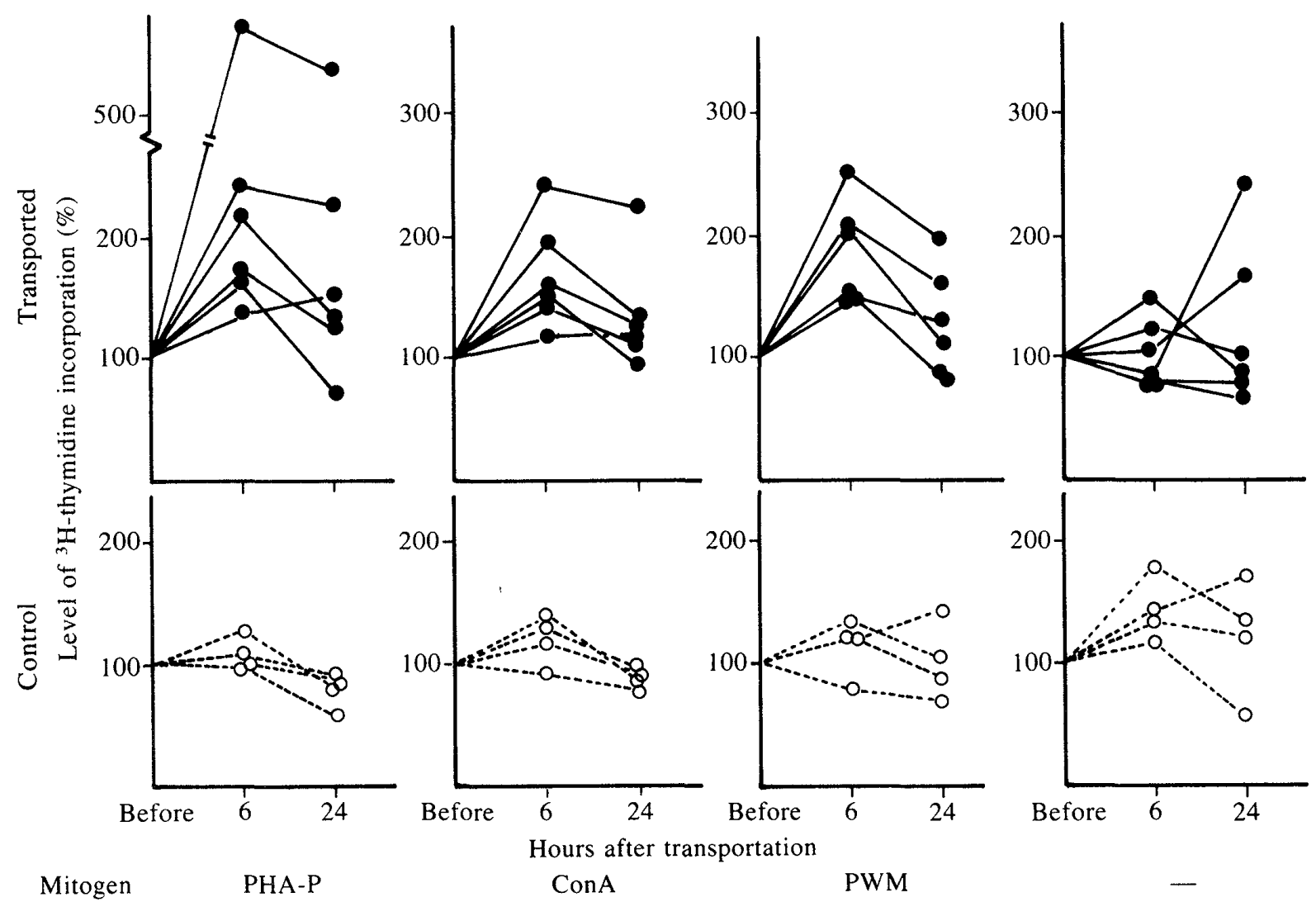

Fig. 1. Change of ${ }^{3} \mathrm{H}$-thymidine incorporation level of lymphocytes.

a) Levels expressed as a percentage rate to the initial level at before-transportation in individual calf.

b) Each filled or open circle represents each calf of the transported or control group, respectively.

humidified air containing $5 \% \mathrm{CO}_{2}$ for 72 hours. Then, $0.2 \mu \mathrm{Ci}$ of ${ }^{3} \mathrm{H}$-thymidine was added to each well. After 16 hours, the cells were harvested onto filter paper. The papers were dried, placed in $3 \mathrm{~m} l$ of toluene-PPO scintillator and counted in a liquid scintillation counter (Aloka LSC-753, Japan). Blastogenesis in each sample was evaluated by stimulation index (SI, $\mathrm{SI}={ }^{3} \mathrm{H}$-thymidine incorporation with mitogen $/{ }^{3} \mathrm{H}$-thymidine incorporation without mitogen).

Phagocyte isolation and NBT reduction test were performed as previously described [8]. Briefly, the blood was centrifuged and plasma and buffy coat layer were discarded. Phagocytes were recovered from the packed erythrocyte later by a hypotonic lysis of erythrocytes and were adjusted to $5.0 \times 10^{6} \%$ $\mathrm{m} l$ in Eagle's MEM. The NBT reduction test was performed by mixing $0.5 \mathrm{~m} l$ of the cell suspension with $0.1 \mathrm{~m} l$ of $10 \mathrm{mg} / \mathrm{m} l$ zymozan A (Sigma, USA) suspension in Eagle's MEM and $0.4 \mathrm{~m} l$ of $1 \mathrm{mg} / \mathrm{m} l$ NBT (Sigma, USA) solution in Hanks' balanced salt solution. After a $30 \mathrm{~min}$ incubation in a $37^{\circ} \mathrm{C}$ water bath, the reaction was stopped by adding $1 \mathrm{~m} l$ of $0.5 \mathrm{~N} \mathrm{HCl}$. After centrifugation, the precipitates were extracted by $3 \mathrm{~m} l$ of dimethylsulfoxide (DMSO) and the optical density (OD) at $565 \mathrm{~nm}$ was determined by a spectrophotometer (Hitachi 220-A, Japan).

Plasma cortisol was determined by a radioimmunoassay kit (Eiken Immunochemical Lab., Japan).

Figs. 1 and 2 show lymphocyte blastogenesis of the calves in both groups. In the transported calves, SI increased 6 hours after the transportation and recovered to the initial level 24 hours after the transportation. SI in the control calves showed no remarkable 


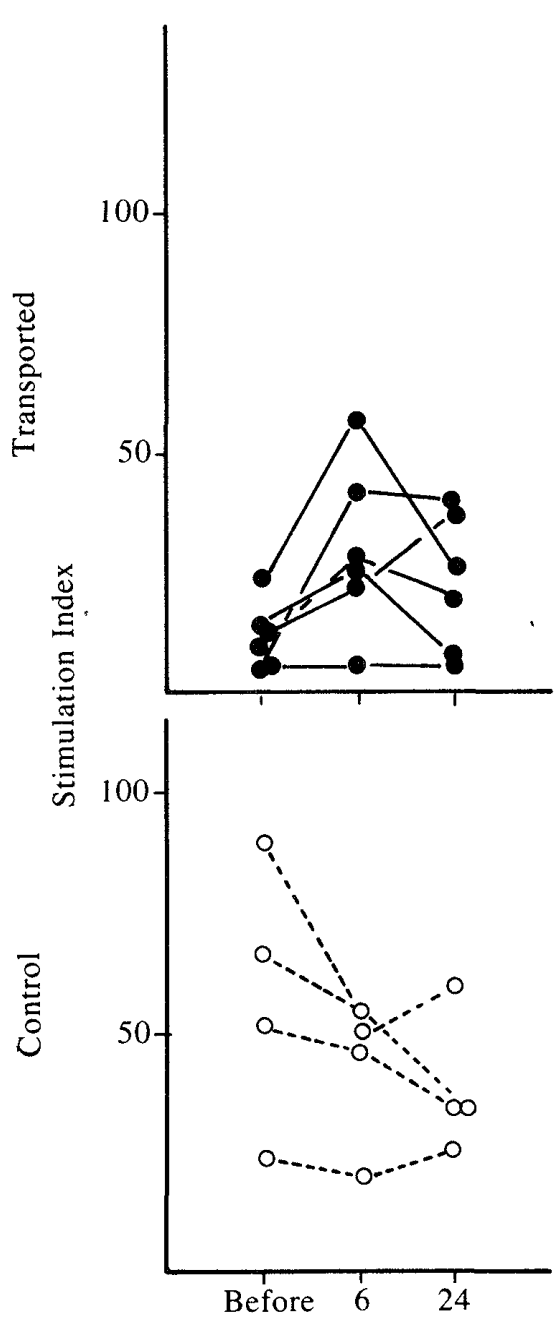

Mitogen

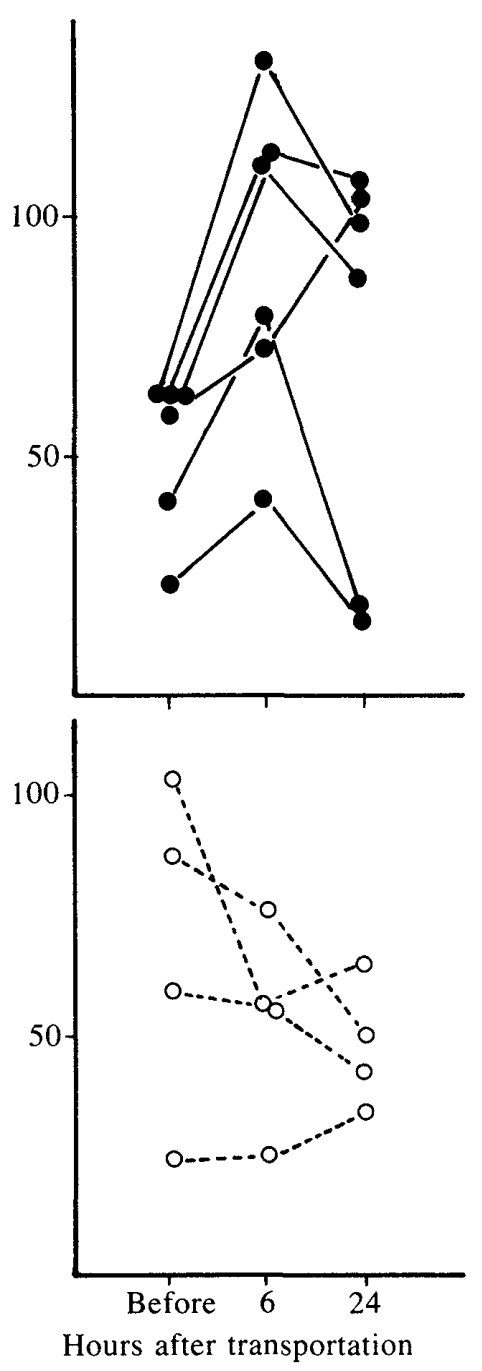

ConA

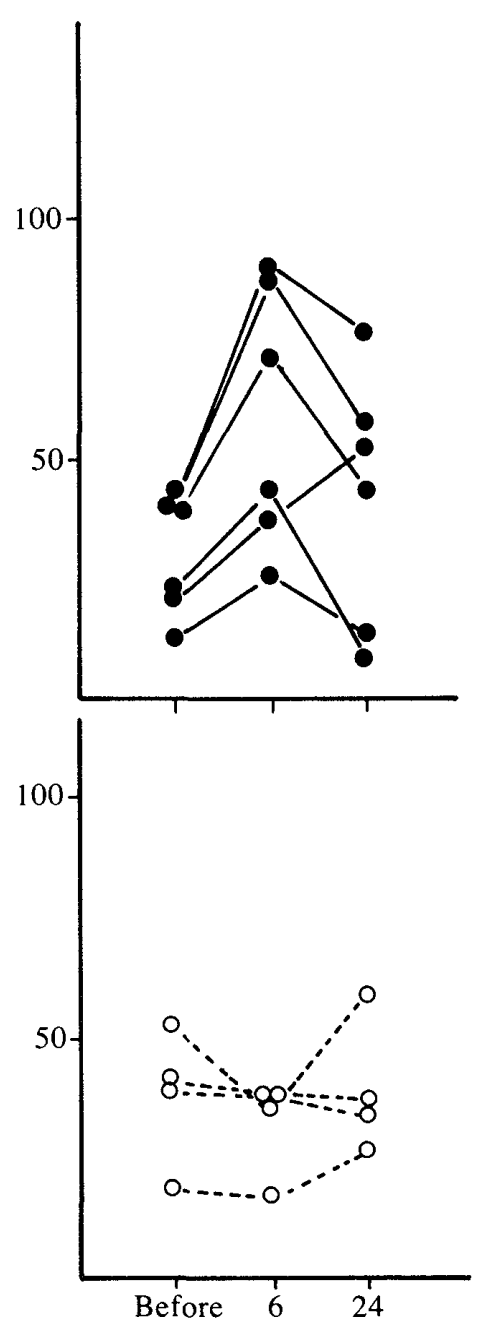

PWM

Fig. 2. Change of Simulation Index in mitogen-induced blastogenesis of lymphocytes.

a) Each filled or open circle represents each calf of the transported or control group, respectively.

change during the experimental period.

NBT reduction activity of phagocytes showed a distinctive increase 6 hours after the transportation in the transported group (Fig. $3)$. The increment returned to the initial level 24 hours after the transportation. In contrast, no change was observed in the control calves.

Plasma cortisol level in the transported group decreased 6 hours after the transportation and it recovered 24 hours after the transportation whereas no change was observed in the cotrol group (Table 1).

In the present study, a temporary but characteristic increase of SI and NBT reduction activity was observed in the transported calves, suggesting an enhancement of lymphocyte and phagocyte activities due to the transportation.

It is known that activities of bovine lymphocytes and phagocytes are affected by the level of glucocorticoids [9-11]. In the present study, the plasma cortisol level of the transported calves were lower and the cellular activities were higher 6 hours after the transportation. The decrease in cortisol level, possibly due to the transportation, might have been responsible for the enhancement of the cellular activities.

On the other hand, Blecha and Minocha [2] have observed a suppression of lymphocyte 


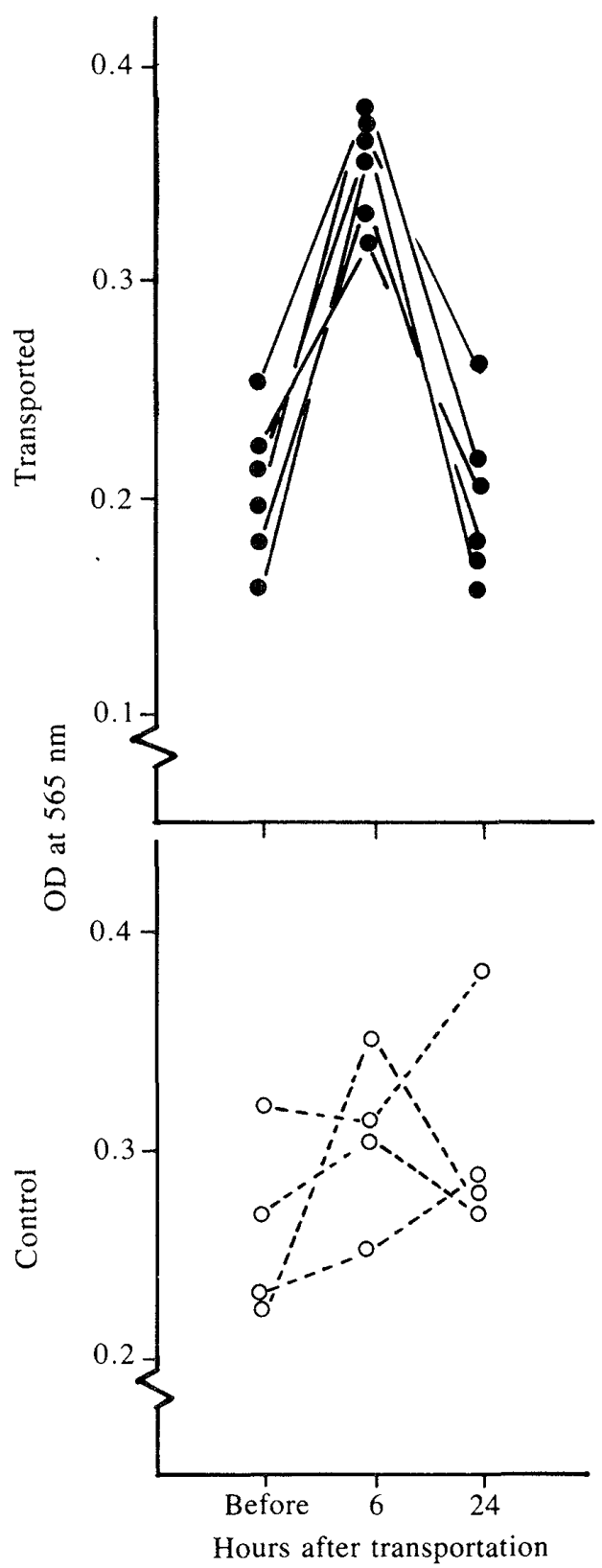

Fig. 3. Change of NBT reduction activity of phagocytes. For further details see Fig. 2. activity corresponding with an elevated plasma cortisol level in calves loaded an acute physical exertion. Also, the same group recently reported an impairment of lymphocyte blastogenic response in calves just after the transportation [1]. Although they reported no remarkable change in plasma cortisol level simultaneously [1], the cortisol level is known to increase rapidly at the initial stage of transportation [7]. Therefore, it seems likely that the elevated cortisol level during transportation induces immunosuppression. In this study, however, such suppression of the cellular activities was not observed. The reason for the difference might be due to the difference in the experimental designs, e.g., sampling frequency or intervals. The suppression might have appeared during and/or just after the transportation prior to the enhancement.

\section{REFERENCES}

1. Blecha, F., Boyles, S. L., and Riley, J. G. 1984. J. Anim. Sci. 59: 576-583.

2. Blecha, F., and Minocha, H. C. 1983. Am. J. Vet. Res. 44: 2145-2148.

3. Hailes, M. R. 1978. Anim. Regul. Stud. 1: 289343.

4. Hartmann, H., Bruer, W., Herzog, A., Meyer, H., Rhode, H., Schulze, F., and Steinbach, G. 1976. Arch. exper. Vet. med. Leipzig 30: 553-556.

5. Kelley, K. W. 1980. Ann. Rech. Vet. 11: 445478.

6. Kelley, K. W., Osborne, C. A., Evermann, J. F., Parish, S. M., and Hinrichs, D. J. 1981. Can. J. comp. Med. 45: 249-259.

Table 1. Change of plasma cortisol level $(\mu \mathrm{g} / \mathrm{d} l)$

\begin{tabular}{lccc}
\hline \multirow{2}{*}{ Group } & \multicolumn{3}{c}{ Stage of sampling } \\
\cline { 2 - 4 } & $\begin{array}{c}\text { Before } \\
\text { transportation }\end{array}$ & \multicolumn{2}{c}{ After transportation } \\
\cline { 2 - 4 } & $1.8 \pm 0.6^{\mathrm{a})}$ & $1.3 \pm 0.4^{\mathrm{a}, \mathrm{b})}$ & $24 \mathrm{hrs}$ \\
\hline Transported & $1.2 \pm 0.2$ & $1.2 \pm 0.2$ & $1.3 \pm 0.6^{\mathrm{b})}$ \\
Control & &
\end{tabular}

Values represent mean \pm standard deviation.

$a, b)$ Means with same letter superscripts are different $(p<0.05)$. 
7. Kent, J. E., and Ewbank, R. 1983. Br. Vet. J. 139: 228-235.

8. Murata, H., Takahashi, H., and Matsumoto, H. 1985. Bull. Nat. Inst. Anim. Health 88: 17-24 (in Japanese with English Summary).

9. Muscoplat, C. C., Shope, Jr., R. E., Chen, A. W., and Johnson, D. W. 1975. Am. J. Vet. Res. 36: 1243-1244.

10. Roth, J. A., and Kaeberle, M. L. 1981. Inf.
Immun. 33: 434-441.

11. Roth, J. A., Kaeberle, M. L., and Hsu, W. H. 1982. Am. J. Vet. Res. 43: 412-416.

12. Simensen, E., Laksesvela, B., Blom, A. K., and Sjaastad, O. V. 1980. Acta Vet. Scand. 21: 278-290.

13. Staples, G. E., and Haugse, C. N. 1974. Br. Vet. J. 130: 374-379.

\section{要 約}

トラック輸送が子牛の細胞性免疫能に及济す影響（短報）：村田英雄・高橋秀之・松本英人（農林水産省家畜 衛生試験場研究第四部) —1 時間のトラック輸送が 6 カ月齢のホルスタイン去勢子牛の細胞性免没能に及注す 影響を，末梢血りンパ球の幼若化能および食細胞の NBT 還元能を指標として検討した。いずれについても輸送 後に一過性の上昇が観察され，輸送に起因した細胞性免疫の交進と考えられた。 